Vitae

Viktoriya Andrushchenko is Doctor of Philology, Associate Professor of Department of English Philology and Translation in Horlivka Institute for Foreign Languages of the State Higher Educational Establishment 'Donbas State Pedagogical University’. Her areas of research interests cover text linguistics, comparative linguistics, functional text stylistics.

Correspondence: andruschenkoviky@i.ua

Надійшла до редакції 1 квітня 2019 року.

DOI 10.31558/1815-3070.2019.37.13

УДК: $811.161 .2 ’ 37$

\title{
СЕМАНТИЧНЕ НАПОВНЕННЯ КОНЦЕПТУ «ЗЕМЛЯ» В РОМАНАХ УЛАСА САМЧУКА «МАРІЯ» І «НА ТВЕРДІЙ ЗЕМЛІ»
}

Розглянуто особливості міфопоетичного сприйняття землі украӥнською лінгвокультурною спільнотою, щуо представляє У. Самчук. Визначено основного вербального репрезентанта концепту «земля» - лінгвокультурему «земля». Проаналізовано семантичне наповнення лінгвокультуреми «земля»в дискурсах романів «Марія» $i$ «На твердій землі». Окреслено головні стилістичні функиії лексеми «земля» як компонента фразеологічних одиниць і художніх тропів (персоніфікаціі).

Ключові слова: концепт, концепт «земля», лінгвокультурема, семантика, фразеологізми, Улас Самчук, украӥнська література $X X \mathrm{~cm}$.

Мовотвочість Уласа Самчука як індивідуально-авторська картина світу та яскравий зразок живого й різнобічного відтворення подій і процесів у сфері української культури та мови XX сторіччя є широким та перспективним грунтом для лінгвокультурологічних досліджень. Актуальним наразі $є$ лінгвокультурний та концептуальний аналізи творів У. Самчука, специфіка процесів вербалізації концептосфери письменника, а саме ключового, наскрізного для його творчих доробків - концепту «земля». Названий концепт характерний для творчості багатьох письменників, що належать до різних лінгвокультур, проте в художній мовній картині світу У. Самчука він, завдяки широкому змісту з розгалуженою формою існування контекстуальних варіантів та емоційно-експресивних оцінок, формує лінгвокультуреми з відповідними значеннями, які відображають особливості лінгвокультури через світогляд автора як іiі представника. Матеріалом дослідження слугували художні тексти У. Самчука «Марія» та «На твердій землі».

Твори У. Самчука стали колом зацікавлення українських літературознавців Р. Гром’яка, А. Жив’юка, I. Качуровського, Р. Мовчан, Н. Пасевич, С. Пінчука, І. Руснак та ін. Лінгвістичну складову текстів автора розглядали Г. Горох, С. Каленюк, В. Стецій. Концептуальний та лінгвокультурологічний аналізи творів письменника проводила у своєму дослідженні Н. Медвідь, сферою іiі наукової діяльності є передусім лінгвокультуреми як вербальне вираження соціально-психологічних концептів. Тему землі у творчості У. Самчука 3 позиції виявлення центрального художнього «макротопоса» розглядає літературознавиця Н. Плетенчук. Науковець акцентує увагу на особливості світобудови тексту У. Самчука, в центрі якої знаходиться Волинь, наголошуючи на свідомій сакралізації цього простору самим письменником шляхом моделювання певних архетипів (Pletenchuk). Дослідниця М. Коновалова, інтерпретуючи роман У. Самчука «На твердій землі», теж торкається тематики землі в контексті зіставлення двох основоположних пластів художньої моделі часопростору - хронотопі великого міста та хронотопі дому (Konovalova). Недостатньо опрацьованим на сьогодні залишається семантично багатокомпонентний складник авторської концептосфери, що наскрізно простежується в усіх творах У. Самчука - концепт «земля».

Науковці виокремлюють кілька основних підходів до розуміння концепту: «культурологічний (Ю. Степанов, Е. Бенвеніст); лінгвокультурний (А. Вежбицька, В. Карасик); психолінгвістичний (В. Красних, Р. Фрумкіна); семантичний (М. Алефіренко, Н. Арутюнова); етнічний (Д. Лихачов, О. Кубрякова, О. Городецька); соціо-психокультурний (Ю. Апресян) і т. ін.» (Kovbasyuk 40). У загальному вигляді трактування цього поняття можна звести до лінгвокогнітивного та лінгвокультурологічного ракурсів, у першому з яких концепт як глобальна ментальна одиниця, ідеальне утворення, що формується у людській свідомості, а в другому - як певний культурний феномен. Безпосередній доступ до всіх концептів (їх утворення, інтерпретація, формування відповідних концептуальних схем, вербалізація) можливий завдяки мові. Увесь масив вербалізованих концептів утворює так звану концептосферу мови. Предметом нашого зацікавлення є, насамперед, концептосфера мови художнього твору, як складна система, що утворюється шляхом перехрещення та нашарування різнорівневих структур, які організують концепти. Українська дослідниця О. Кагановська визначає текстовий концепт як «мовленнєво-розумове утворення змістового плану, яке характеризується багатосмисловою напруженістю й надкатегоріальністю і на текстовому рівні імплікує сукупність певних ознак метаобразів художнього твору з метою їхньої подальшої імплікації»

(C) Артемова Ю., 2019 
(Kahanovs'ka 24). Зв’язок концептуальних ліній тексту формує його концептуальну структуру (Selivanova, «Suchasna linhvistyka» 418). Концептуальний аналіз художнього твору дає можливість розкрити мовне бачення світу, характер організації семантики мовного простору творчої особистості, розгледіти як притаманний тільки ій, індивідуальний тип знань про світ, так і простежити етноконцепти та загальнолюдські концепти (Selivanova, «Pryntsypy kontseptual'noho analyza» 12) в художньому творі як еталонному згустку лінгвокультурної інформації конкретної доби, що представляє автор.

Концепт «земля» в колективній свідомості українців як окремої мовної спільноти існує у вигляді розгалуженої системи конотацій $з$ яскраво вираженою динамікою його лексико-семантичної структури від конкретнопредметного до поняттєвого значення. Цей концепт має властивість проявлятися в окремому дискурсі у вигляді лінгвокультурем, формами вираження яких можуть бути лексичні одиниці та словосполучення, фразеологічні словосполучення, паремійний фонд, прецедентні тексти.

Основним вербальним репрезентантом концепту, його власною формою, ключовою лексемою є так зване ім’я концепту. В нашому випадку іменем концепту «земля» $є$ лінгвокультурема «земля», яка і $є$ наразі предметом цієї розвідки. Та варто зазначити, що сукупність інформації, що несе в собі концепт, вербалізується однією лінгвокультуремою лише частково, тому повноцінно його структура може бути виражена сукупністю таких одиниць. Поза тим лінгвокультурема «земля» як ядро концепту характеризується багатим семантичним наповненням, і іï значення, що в одному дискурсі представляють основні характеристики концепту в іншому, можуть відноситися до периферійних і навпаки. Саме така варіативність і розгалуженість концептосистеми «земля» $\epsilon$ характерною для аналізованих нами художніх текстів. Великої уваги заслуговує саме ядро, номінація концепту лексема «земля». Тож метою цієї розвідки є: з’ясувати особливості семантичного наповнення концепту «земля» вербалізованого в творах однойменною лінгвокультуремою. Задля досягнення вищевказаної мети ставимо перед собою такі завдання: з'ясувати особливості міфопоетичного сприйняття землі українською лінгвокультурною спільнотою, що представляє письменник; віднайти та порівняти всі значення, конкретно-образні й абстрактні характеристики й ознаки лінгвокультуреми «земля» у творах У. Самчука «Марія» і «На твердій землі», проаналізувати наявні фразеологічні словосполучення з компонентом «земля», а також статистично вирахувати кількість даних слововживань у двох текстах.

Першопочатком визначення образу будь-якого народу, його зовнішнім показником є середовище - територія, на якій він проживає. Визначальним фактором у формуванні стереотипів, еталонних образів, міфологем, загалом вироблення психокультури окремого народу є його земля, як частина території зі всіма належними їй кліматичними та рельєфними особливостями. Саме ці чинники здатні впливати і визначати специфіку життєдіяльності як індивідів, так і загального колективу, обумовлювати спосіб життя народу та характер його основних занять. На цьому грунті усталюється і лінгвокультурний запас окремої спільноти як носія народнокультурної інформації.

Специфіка міфопоетичного сприйняття землі українцями характеризується через сакральні сфери, на основі християнських та дохристиянських вірувань слов'ян. За етнолінгвістичним словником, земля - «одна з основних стихій світобудови (поряд з водою, вогнем і повітрям); центральна частина тричасткового Всесвіту (Небо - земля пекло), населена людьми і тваринами; символ жіночого плодоносного початку, материнства; осмислювалася як прародителька й годувальниця всього живого» (Belova, Vynohradova, Toporkov 315). Земля як першоелемент при уявленні про походження людини спостерігається в народних легендах, апокрифічній літературі, Біблії: «І створив Господь Бог людину з пороху земного. І дихання життя вдихнув у ніздрі іiі, і стала людина живою душею» (Бут. 2: 7). За Біблією все подальше життя людини та в підсумку її смерть мають безпосередній зв'язок із землею: «І вислав його (Адама-авт.) Господь Бог із еденського раю, щоб порати землю, з якої узятий він був» (Бут 3: 23); «У поті свойого лиця ти їстимеш хліб, аж поки не вернешся в землю, бо з неї ти взятий. Бо ти порох, i до пороху вернешся» (Бут 3: 19). У слов'ян фіксується факт нашарування та переплетення дохристиянських, язичницьких традицій, вірувань, повір'їв із християнськими. Етнограф Г. Булашев зазначає, що у свідомості українців «з одного боку, під видимим християнським зовнішнім виглядом тримались рештки язичництва, а 3 другого боку, нове вірування переінакшувалося й засвоювалося під впливом давньої міфології» (Bulashev 41). Таке взаємопроникнення різних за своєю суттю понять можна простежити на прикладі уявлення слов'ян про землю. Так через процес персоніфікації землі створюється символ жіночого начала шляхом усвідомлення ії як жінки, «що спить, вагітніє, народжує, стогне і плаче перед бідою, гнівається на людей за гріхи (не дає врожаю)» (Belova, Vynohradova, Toporkov 316); з подальшою метафоризацією материнства та зближенням з образом Божої Матері та в підсумку ототожненням характеристики святості (свята земля).

Характерним для українців, як і для інших слов'янських народів, є наділення землі лікувальними, цілющими, магічними властивостями. Земля як сильний атрибут нерідко виступає у різного роду магічних обрядах як 3 позитивною, так із негативною конотацією. Такі ритуали часто можуть супроводжуватися підсиленням за допомогою заклинань чи замовлянь із застосуванням номінації «земля» або «сира земля-мати» як персоніфікованого образу землі у слов'янській міфології. Надзвичайну силу, за віруваннями давніх слов'ян (як східних, так і західних), мали прокляття, пов’язані з землею, що зазвичай виступали як побажання смерті: укр. закарпат. «Земля бы ти побила», «Земля бы тя промкла», «Наївбися сырої землі»; бел. «Каб на твае вочы людзі зямлю сыпали!», «Каб ён сам шчарнеу як зямля!»; болг. «Тая земя у очите му отива» [Ця земля очі йому засипить], пол. «Żebyś się w ziemnię zapadł» [Щоб ти в землю пропав] (Belova, Vynohradova, Toporkov 318). Уявлення про землю також безпосередньо пов'язані з поняттям свого роду, Батьківщини. Так, при переселенні перед від’їздом брали з собою жменю землі для того, щоб краще прижитися в новій місцевості та не сумувати за рідним краєм або ж для того, щоб під час поховання людини рідну землю сипали на їі могилу (Belova, Vynohradova, Toporkov). 
Визначивши текстову семантику імені концепту «земля» і з'ясувавши особливості їі функціонування в проаналізованих нами художніх творах шляхом застосування методу контекстуального аналізу, можемо констатувати наявність цієї лінгвокультуреми у різних значеннях з різним семантичним наповненням. У текстах представлені значення лексеми «земля», зафіксовані у Словнику української мови в 11 томах: 1) тільки одн. Третя по порядку від Сонця велика планета, яка обертається навколо своєї осі і навколо Сонця; // Місце життя і діяльності людей; 2) тільки одн. Верхній шар земної кори; // розм. Земляна поверхня, площина, по якій ходять; 3) тільки одн. Речовина темно-бурого кольору, що входить до складу земної кори; 4) тільки одн. Суша (на відміну від водяного простору); 5) Грунт, який обробляється і використовується для вирощування рослин; 6) Країна, край, держава (SUM 3: 557.). Узагальнені дані частотності появи лінгвокультуреми «земля» і різних ії граматичних форм у вищевказаних значеннях та окремо як компонента фразеологічних словосполучень у романах «Марія» та «На твердій землі» наведено в таблиці 1.

Таблиця 1

\begin{tabular}{|c|l|c|c|}
\hline \multirow{2}{*}{ № 3/п } & \multicolumn{1}{|c|}{ Семантика лінгвокульуреми «земля» } & $\begin{array}{c}\text { «арія», } \\
\text { од. }\end{array}$ & $\begin{array}{c}\text { «На твердій } \\
\text { землі», } \\
\text { од. }\end{array}$ \\
\hline 1 & $\begin{array}{l}\text { Третя по порядку від Сонця велика планета, яка обертається навколо своєї осі } \\
\text { і навколо Сонця }\end{array}$ & 5 & 6 \\
\hline 2 & Місце життя і діяльності людей & 24 & 25 \\
\hline 3 & Верхній шар земної кори & 12 & 6 \\
\hline 4 & Земляна поверхня, площина, по якій ходять & 25 & 11 \\
\hline 5 & Речовина темно-бурого кольору, що входить до складу земної кори & 13 & 7 \\
\hline 6 & Суша (на відміну від водяного простору) & 3 & 1 \\
\hline 7 & $\begin{array}{l}\text { Врунт, який обробляється і використовується для вирощування рослин (як } \\
\text { власність) }\end{array}$ & 45 \\
\hline 8 & Країна, край, держава & 10 & 6 \\
\hline 9 & Фразеологізми з компонентом «земля» & 12 & 17 \\
\hline 10 & Усього: & 149 & 4 \\
\hline
\end{tabular}

У значенні планети лінгвокультурема «земля» в обох романах зустрічається порівняно рідко, при чому лише в одному з таких випадків автор вживає цю лексему з великої літери: «...а по деревах нервово осідають $i$ їжаться випари праџьовитої вертухи Землі, коли сад обертається у кораловий чагарник $і$ стоїть непорушне, зачаровано, залитий мідяним зором неба...» (Мар. 138); «Не було вже часу, земля крутилася $і$ до нас, але ми все таки, навчені досвідом наших перших дитячих кроків, вдавали також божевільних доляро-робів...» (На тв. 3. 275). Значно частіше у творах представлена лінгвокультурема «земля» як «місце життя і діяльності людей», характеристику величини та багатогранності якої автор підсилює сталою лексичною конструкцією «по (на) всій (цілій) землі»: «Гнат мовчки сидить, і в душі його воскресають мертві з гробів, встають з домовини люди, далекі, забуті, розкидані по всій землі» (Мар. 212), а також епітетними формулами: «Земля наша велика... Заселяй, засипай людьми» (Мар. 99); «...пророкували бородачі, щуо настане брань велика і поллється скрізь, як широка земля, людська кров» (Мар. 128); «За ціле моє різно-многогранне буття на цій строкатій землі, не так часто приходилось бачити зблизька подібні явища...» (На тв. з. 76). Варто наголосити на тому, що лінгвокультурему «земля» в цьому ж значенні У. Самчук досить часто вводить у конструкцію з бінарною опозицією «земля / небо», яка загалом є однією з показових в аспекті мовної об'єктивації світогляду людини, системи іії цінностей та особливостей світосприйняття (Zhayvoronok): «Це не значить, щзо вона не бачила неба й землі» (Map. 17); «Дзвони дзвонять, сміється небо і земля» (Мар. 120). Маючи на увазі простір перебування людей, предметів, інших об'єктів дійсності, автор використовує сталу сполуку «між небом і землею» в прямому значенні: «Мені завжди здавалося, щзо всі дахи, яких стільки набудовано по всій землі, красуються собі між небом $і$ землею..." (На тв. з. 8), а також як фразеологізм, що означає «перебувати у невизначеному, непевному становищі»: «Я опинився в порожнечі, між небом і землею, без права на власне місие» (На тв. 3. 64).

У другому значенні лінгвокультурема «земля» зустрічається здебільшого в його розмовному (за словником) варіанті. Показовим є використання лінгвокультуреми земля (поверхня) в образних формах, аналіз яких приводить до загального образно-емоційного фону текстів. Так для роману «Марія» характерні сполуки 3 дієсловами спадати, припадати, прилипати, кланятися та прийменником до: «Чорна в шоломі постать згорбилася, мов кишеньовий ніж, і припала до землі» (Мар. 143); «Гнувся лозою, прилипав до землі листом, якого зірвала буря, не раз ставав зовсім непомітним, ніби він натягнув на себе шапочку-невидимку» (Мар. 195), у значенні напрямку вниз як явища орієнтаційної метафори (Lakoff, Johnson), де когнітивний механізм аналогізації векторів «униз-назад-ліворуч» завжди з негативною оцінністю (Selivanova, «Suchasna linhvistyka»). Схожий значеннєвий відтінок у розумінні «гірко побиватися, бути у відчаї» має словосполучення битися об землю: «Пам'ятаєм, як ти молилася в цеекві, а вернувшись, билася об землю і ридала?» (Мар. 212). Непевність, затьмарення, запаморочення означає лінгвокультурема «земля» в такому контексті: «Земля підіймaється й опускається» (Мар. 68). На противагу, в романі «На твердій землі» наявне в назві твору словосполучення письменник вживає декілька разів, розкриваючи цією метафорою відчуття сталості, стабільності, впевненості в сьогоденні: «...niсля довгого 
одісейного блукання по широкому, розбурному світі, я ступив нарешті на тверду землю великого, спокійного континенту з його іншим, відмінним ладом, до якого я не мав доступу...» (На тв. з. 5). Як «верхній шар земної кори» слово земля автор використовує переважно в значенні певного рівня, відносно якого щось (хтось) знаходиться чи відбувається та використовує їх із просторовими прийменниками над та під: «Низько над землею розливається ледь чуйна хвилька самогонного випару» (Мар. 138); «Трансконтинентальні дороги підуть під землею, транслетунські у стратосферу» (На тв. з. 372). Також назване значення розкривається в лексемах іншої частиномовної приналежності, а саме прикметниках «надземний», «підземний», «поземний»: «Це буде імперія надземних, поземних і підземних доріг, гантарів, полярних гаражів, міжплянетних летовищз» (На тв. 3. 330); «Він згадав, щчо знадвору до колодязя веде завалений підземний хід» (Мар. 193), та похідному іменнику підземелля: «Здавалось, мій голос виходив з підземелля, з якогось льоху за семи замками» (На тв. 3. 233).

Земля у значенні речовини темно-бурого кольору представлена в текстах у складі відповідних словосполучень, що розкривають ії якісні характеристики (колір, стан, запах і т. д.): «Земля чорна, пшениия, хміль, буряк жене без гною» (Мар. 26); «У відталій землі на картоплищзі можна гнилу картоплину знайти» (Мар. 202); «Навіть від мокрої землі відчувається» (Мар. 205); «...ия запопадлива господиня відкривала біля дому безодню безобразної наготи, сита, пахуча земля вимагала уваги...» (На тв. з. 355). У складі постійного епітета сира лінгвокультурема «земля» відсилає до слов'янської міфології та дає вказівку на дуалістичний зв'язок стихій землі й води як необхідної умови для зародження нового життя, а також із паралельним протилежним значенням, в якому сира земля найчастіше асоціюється зі смертю, могилою: «Іили з тим трактором, співали йому, обвивали вінками, чіпляли на нього прапори, кланялись йому до землі сирої» (Мар. 175); «Горнулася до сирої землі, яка забрала ї̈ хлопчика, ї̈ Романя, $і$ благала розійтися, забрати до себе і маму» (Мар. 66).

У розумінні суші лінгвокультурему «земля» автор вводить у речення в контексті протиставлення до водяного простору і в аналізованих нами текстах використовує це значення лиш декілька разів: «На кожному кроці море каже тобі: "Ти є ніщчо, людино, в порівнянні зо мною. Стань тільки на поверхню мою і погрузнеш..." А подивися - земля. Чим сильніше станеш, тим певніший... Земля і море... Так воно...» (Мар. 98); "...коли все видається легким, досяжним, коли то якийсь моряк з далекого рейду, щуо вирвався з обіймів стихї моря $i$ потрапив у стихію землі» (На тв. з. 171).

Як грунт, що обробляється і використовується для вирощування рослин лінгвокультурема «земля» статистично багатше представлена в дискурсі роману «Марія», що зумовлено тематикою твору. Для даного тексту лінгвокультурема в цьому значенні є ключовою та визначальною, адже схематично за сюжетом можна узагальнити таку взаємозалежність: земля = хліб = життя. Земля, що в буквальному значенні годує селянина, стає його найзаповітнішим бажанням, єдиним засобом для існування. Тому в даному контексті до сформульованої в словнику дефініції землі в розумінні грунту можна додати ще одне значення: ‘земля як власність ': «Під селянськими стріхами гуторили на всі лади про землю. Земля, земля й земля. Дайте нам землі! Той, хто дасть селянам землю, той здобуде душу народу! Треба землі, мало землі, народ не може без землі! ... Нащу взагалі йіле життя, иіла та імперія, яка має безліч землі, а селянин тиснеться на клаптику поля, де не має місия поставити порядний будинок? Революиія! Робіть революичю! Землі-і-i! Землі-i-i!..» (Мар. 134). Щодо твору «На твердій землі» то тут таке значення практично не представлене лінгвокультуремою «земля», натомість автор вербалізує його лексемою трунт: «Наші справи набирали форми, мені особисто вдалося набути нову ділянку трунту, я обвантажився новими боргами» (На тв. 3. 378).

Лінгвокультуремою «земля» вербалізується також значення «країна, край, держава», що деталізується узгодженими (рідна, наша, ваша, одна, своя, моя) і неузгодженими (України, предків) означеннями: «Гірко з домою та землею рідною прощатися» (Мар. 102); «Земля моӥх предків далі моя земля, з неї зліплена моя плоть i моя кров, $і$ мій дуx, i моє минуле» (На тв. 3. 354). Показовою є також характеристика письменником землі як краю, що настроєво значно різниться у двох текстах - якщо в «Марії» «Земля України дуднить» за неї «наші брати ллють свою кров», на ній «нема неголодного місия», то в романі «На твердій землі» канадська земля «благодатна, сита», «проста, виразна, пречудова»; «нова, гарна, багата, велика, свобідна», «тверда», земля «мудрої праці і великої свободи». У підсумку в названих дискурсах таке семантичне навантаження лінгвокультуреми «земля» створює особливий емоційний фон, коли в одному випадку він сповнений безпорадності, тривожності, болю, відчаю, то в другому - впевненості, стабільності, віталізму.

Задля увиразнення та експресивності У. Самчук також використовує в текстах фразеологічні одиниці 3 компонентом земля. Так, у значенні «дуже швидко» (Bilonozhenko 332) задля підсилення дієслова руху бігти автор вживає фразеологізм землі не чути: «Марія біжить стежкою під гору, землі не чує» (Мар. 38); «Біжить, йойкає, землі не чує» (Мар. 110). Інше стійке словосполучення кинути (ударити) лихом об землю використане письменником з позитивним змістовим наповненням для потужного стилістичного ефекту та означає «забувати біду, горе, не журитися» (Bilonozhenko 911): «Не сумуй. Кинь лихом об землю. Перемелеться мука буде» (Мар. 42). У такому ж значенні (як поверхня) компонент «земля» знаходиться у складі стійкого словосполучення поклонитися до землі в розумінні «низько схилятися, виражаючи пошану» (Bilonozhenko 2, 912): «Підійти до неї, стати прилюдно на коліна і поклонитися до землі» (Мар. 55). Речовинне значення компоненту простежується у фразеологізмі засипати землею, яка наповнена негативною семантикою смерті, поховання та означає «похоронити» (Bilonozhenko 1, 317). При його використанні автору вдається створити комічний ефект через зображення нерозуміння дитиною образності цього словосполучення: «-Нема. Засипали землею. -Оксана втирає сльози - Засипали землею... Татові буде тязко» (Мар. 21). Таке ж значення простежуємо й у фразеологізмі живцем у сиру землю в другому творі письменника: «...сипались тонни вибухових об 'єктів, а ми, побравшись за 
руки, намагалися лізти живцем у сиру землю, дихали диханням могили, тремтіли разом з плянетою...» (На тв. 3. 44). Фразеологізмом із позитивною конотацією є словосполучення земля обіияна (обітована) у значенні «багатий, розкішний край, де панує повний достаток і злагода» (Bilonozhenko 1, 333): «I xто знає, чи не в ту долину, де починається "земля обіцяна", яку можна бачити, як на ласкавій Божій долоні, з непередмірного висока» (На тв. 3. 345). Охарактеризувавши наявні в двох текстах фразеологічні одиниці з компонентом «земля», можемо констатувати більшу їх присутність у романі «Марія», що, на нашу думку, зумовлюється яскраво вираженою народно-поетичною образністю твору.

Характерною для мовної особистості У. Самчука є свідома персоніфікація образу землі, як виразний стилістичній ефект, в результаті якого земля стає ще одним окремим персонажем твору. Притім така персоніфікація відбувається в декількох значеннях даної лінгвокультуреми. Найбільше випадків уособлення землі у творі «Марія» простежується в значенні ії як планети: «Між тим земля поволі оберталася обличчям до сония...» (Мар. 79); «Земля повертає боки» (Мар. 19); «...а по деревах нервово осідають і їжаться випари працьовитої вертухи землі» (Мар. 138); “Корчилася сердитим кулаком земля і натягала м'яку білу рукавицю» (Мар. 19). Як місце життя і діяльності людей: «Земля захотіла бути нарешті порожньою...» (Мар. 189). У значенні грунту персоніфікований образ землі набуває фемінних рис та характеристик материнства, відсилаючи нас таким чином до міфопоетичного його сприйняття: «Усе тоді родить - земля $i$ ти» (Мар. 99); «Геть, як гляне око, стелиться сонячний легіт, мліє земля. Здається, твориться святе таємство опліднення» (Мар. 206). Як родючий грунт земля є одухотвореною і в романі «На твердій землі»: «...сита, пахуча земля вимагала уваги, вже у квітні ми з Катрусею почали наші муравлині заходи з лопатами, рискалями, граблями...»; «Коли я торкався землі, вона хапала мене, як павук муху, і катувала мене своєю ненаситністю» (На тв. 3. 355). Задля піднесення, увиразнення позитивного ставлення героя до землі як краю теж використано персоніфікацію: «Земля жеива й насторожена, вона плянує свою казку майбутнього і розказує ї̈ вітрам, деревам, воді...» (На тв. 3. 66). Зрештою таке уособлення образу землі автором пояснюється великою традиційною його пошаною до цієї стихії, яка загалом притаманна для всієї української етнокультури. Тому земля у творах У. Самчука «вимагає праці $i$ поту», «ласкаво приймає», «земля не сміє гуляти» «не буде чекати», «вимагає уваги», «годує», «сміється», «виспівує».

Отже, для лінгвокультуреми «земля», як слова, що «супроводжувало народ протягом віків існування і було поруч у різні щасливі, а також трагічні моменти історії, характерні семантичні, стилістичні та безліч асоціативних зв'язків» (Sovtys 43). Воно належить до основних, базових світоглядних кодів української лінгвокультури, адже саме земля є визначальним елементом буття народу, фактором його існування. Таке архетипне колективне сприйняття образу землі з подальшою його концептуалізацією та вербалізацією й обумовлює значну кількість різнопланових конотацій слова. Проаналізувавши назву концепту «земля» в романах У. Самчука «Марія» і «На твердій землі», констатуємо іï багате семантичне наповнення. Ця лексема представлена в текстах у всіх зафіксованих словником значеннях, проте в різній кількості. Показовою є статистика слововживань лінгвокультуреми «земля» у двох творах: кількісно більше вона в різних граматичних формах наявна у романі «Марія» (149 слововживань), серед яких найчисельніше представлене значення «Грунт, який обробляється і використовується для вирощування рослин» (45 випадків). Слово «земля» у цьому значенні стає ключовим для названого твору і створює його відповідний контекст. У романі «На твердій землі» 3-поміж усіх випадків вживання лінгвокультуреми «земля» (83) найчастіше виражене значення «місце життя і діяльності людей» (25 слововживань). Це зумовлено тим, що твір має філософське спрямування на противагу соціально-психологічному роману «Марія». Окрім кількісних характеристик варто відзначити також виразні стилістичні функції лінгвокультуреми «земля» і як однієї лексеми, і у складі лексичних словосполучень. Цей активно вживаний автором компонент є семантично розгалуженим мовноестетичним знаком національної культури і динамічність його семантичної структури сприяє його активному входженню також до складу фразеологічних одиниць і художніх тропів (зокрема персоніфікації), що зумовлює різні стилістичні ефекти, від гумористично, комічного настрою до негативного забарвлення.

Окрім самого імені, ядрового компонента «земля» у всіх вищевказаних значеннях, сам концепт вербалізується в текстах й іншими лінгвокультуремами, які створюють розгалужені концептуальні структури аналізованих художніх творів. Аналіз цих структур шляхом застосування методу лінгвокультурологічного поля дасть можливість стверджувати про відмінність у двох текстах встановлених ієрархічних зв'язків між лінгвокультуремами. Саме в характеристиці таких зв'язків, у реконструкції всього лінгвокультурологічного поля концепту «земля» $\mathrm{i}$ вбачаємо перспективу подальших досліджень.

\section{References}

1. Belova, Ol'ha, Vynohradova, Lyudmyla and Andrey Toporkov. Zemlya. Slavyanskye drevnosty (Earth. Slavic antiquities). Etnolynhvystycheskyy slovar' $v 5 t$. (Ethnolinguistic dictionary in 5 vol.) Moskva: Mezhdunarodnie otnoshenyya, 1999 (2). 315-321. Web. 24 Feb. 2019.

2. Bibliya: Svyate pys'mo (pereklad Ivana Ohiyenka) (Bible: Holy Scripture (translated by Ivan Ogienko)). Kyiv: Asotsiatsiya «Dukhovne vidrodzhennya» / Mission Eurasia: Doroha Pravdy: Knyhonosha, 2015. Print.

3. Bilonozhenko, Vira. Frazeolohichnyy slovnyk ukrayins'koyi movy (Phraseological Dictionary of the Ukrainian Language). Kyiv: Naukova dumka, 1993 (1-2). Web. 01 Mar. 2019.

4. Bulashev, Heorhiy. Ukrayins'kyy narod u svoyikh lehendakh, relihiynykh pohlyadakh ta viruvannyakh. Kosmohonichni ukrayins'ki narodni pohlyady ta viruvannya (Ukrainian people in their legends, religious views and beliefs. Cosmogonic views and beliefs of Ukrainian people). Kyyiv: Dovira, 1992. Web. 24 Feb. 2019. 
5. Kahanovs'ka, Olena. Tekstovi kontsepty khudozhn'oyi prozy (na materiali frantsuz'koyi romanistyky seredyny XX storichchya) (Textual concepts of artistic prose (based on the material of French romantics of the mid-twentieth century)). Kyiv: Vydavnychyy tsentr KNLU, 2002. Print.

6. Konovalova, Mariiya. Osoblyvosti chasoprostorovoyi orhanizatsiyi romanu Ulasa Samchuka «Na tverdiy zemli» (Features of time-space organization of Ulas Samchuk's novel «On Firm Ground»). Naukovyy visnyk Mykolayivs'koho natsional'noho universytetu imeni V. O. Sukhomlyns'koho. Filolohichni nauky (Scientific Herald of the Mykolaiv National University named after Vasyl' Sukhomlynsky. Philological sciences) 1 (2015): 87-91. Web. 05 Feb. 2019.

7. Kovbasyuk, Larysa. Suchasni linhvistychni teoriyi: lektsiyni, praktychni, samostiyni moduli ta testy. (Modern linguistic theories: lectures, practical, independent modules and tests ). Kherson: Vyd-vo KhDU, 2008. Print.

8. Lakoff George, Johnson Mark. Metaphors We Live By. University of Chicago Press, 2003. Web. 15 Feb. 2019.

9. Pletenchuk, Nataliiya. Khudozhniy fenomen sakralizatsiyi volyns'koho makrotoposa v prozi Ulasa Samchuka (The artistic phenomenon of the sacralization of the Volyn`s macro topos in prose by Ulas Samchuk). Pytannya literaturoznavstva (Questions of the literature studies) 83 (2011): 163-172. Print.

10. Selivanova, Elena. Pryntsypy kontseptual'noho analyza (Principles of conceptual analysis). Aktual'ni problemy mentalinhvistyky (Actual problems of mental linguistics). Kyiv-Cherkasy, 1999. Print.

11. Selivanova, Olena. Suchasna linhvistyka: napryamy i problemy (Modern Linguistics: Directions and Problems). Poltava: Dovkillya-K, 2008. Print.

12. Slovnyk ukrayins'koyi movy. V 11 tomakh (Dictionary of the Ukrainian language. In 11 volumes) Kyiv: Naukova dumka, 1970-1980. Web. 15 Feb. 2019.

13. Sovtys, Nataliia. Klyuchovi slova ta nabuvannya nymy symvolichnykh znachen' u khudozhn'omu tvori (Keywords and their acquisition of symbolic meanings in a work of art). Naukovi zapysky Nizhyns'koho derzhavnoho universytetu im. Mykoly Hoholya. (Scientific notes of the Nizhyn State University named after Mykola Gogol) 2 (2012): 43-46. Web. 10 Mar. 2019.

14. Zhayvoronok, Vitaliy. Ukrayins'ka etnolinhvistyka: Narysy (Ukrainian ethnolinguistics: Essays). Kyiv: Dovira, 2007. Print.

\section{List of Sources}

1. Samchuk, Ulas. MARIIA: khronika odnoho zhyttya (MARIIA a Chronicle of One Life). Kyiv: Smoloskyp, 2009. Print. 2. Samchuk, Ulas. Na tverdiy zemli (On Firm Ground). Toronto: Ukr. Kredytova Spilka Toronto, 1967. Print.

\section{List of Abbreviations}

1. Бут. - Книга Буття (Bibliya: Svyate pys'mo (pereklad Ivana Ohiyenka) (Bible: Holy Scripture (translated by Ivan Ogienko)).

2. Map. - Samchuk, Ulas. MARIIA: khronika odnoho zhyttya (MARIIA a Chronicle of One Life).

3. На тв. 3. - Samchuk, Ulas. Na tverdiy zemli (On Firm Ground).

\section{SEMANTIC INTERPRETATION OF «GROUND» CONCEPT IN ULAS SAMCHUK'S NOVELS «MARIIA» AND «ON FIRM GROUND» \\ Yuliia Artemova}

Department of Ukrainian language named after prof. Kalenyk Shulzhuk of Rivne State University of Humanities

Abstract

Background: «Ground» concept is a core element of U. Samchuk's sphere of concepts as well as of Ukrainian people in general. Thanks to verbalization of the above-mentioned concept in imaginative composition as part of linguocultural information of specific cultural society represented by the writer, it reflected authors and collective apprehension of the image of «Ground». The analysis of semantic interpretation of «Ground» concept in U'Samchuk's novels «Mariia» and «On firm Ground» enables to follow up the specifics of generation of this type of archetype in the language image of the author's world.

Purpose: The purpose of such analysis is to find and compare all meanings, specifically imaginative and abstract characteristics of «Ground» concept in U'Samchuk's novels «Mariia» and «On firm Ground» as well as definition of their stylistic functions.

Results: Name of the «Ground» concept in U. Samchuk's novels is characterized by rich semantic interpretation, which is fully displayed in the context of novels. One can notice writer's evolution of perception of the ground image from specific conceptual, soil as the main means of existence in «Mariia» to imaginative philosophic meaning of the place of living and activities of people in «On firm Ground» novel. Phraseological units with «Ground» component as act imaginative means of reflection of life situations, cases and life events, and also as means for reflection of the era coloring and national surroundings. Their use causes different stylistic effects, starting from humoristic, comic mood to negative one. The author's typical tool is personification of grounds' image from vivid emotional estimating expression. By making ground possess human characteristics one can notice extreme respect of Ukrainian people to it.

Discussion: Information with «Ground» concept is only partially verbalized by «Ground» linguocultureme, that's why its structure can be fully described by combination of units making multiple conceptual structures of these novels. Analysis of these structures will enable to approve difference of established hierarchic relations between linguoculturemes.

Key words: concept, «Ground» concept, linguocultureme, semantic interpretation, Ulas Samchuk, Ukrainian literature of the XX century. 
Vitae

Yulia Artemova - second year postgraduate of the specialization 035 "Philology" of the department of Ukrainian language named after prof. Kalenyk Shulzhuk of Rivne State University of Humanities. Sphere of her scientific interests are linguocultural studies, cognitive linguistics, cognitive semantics, linguoconceptology, text linguistics.

Correspondence: jartemova18@gmail.com

Надійшла до редакції 25 березня 2019 року.

DOI 10.31558/1815-3070.2019.37.14

УДК 81 '42-028.61

\section{РЕГУЛЯТИВНІ СТРАТЕГІЇ Й ТАКТИКИ В СУЧАСНІЙ УКРАЇНСЬКІЙ ХУДОЖНІЙ ПРОЗІ}

Ідеться про регулятивну стратегію як вектор мовленнєвої поведінки адресанта, щзо передбачає спеціальне оброблення художнього повідомлення з метою оптимального порозуміння з адресатом в умовах асинхронної комунікаціі. Запропоновано класифікацію регулятивних стратегій сучасного художнього прозового тексту, з'ясовано їхні основні та допоміжні тактики. Продемонстровано, щуо регулятивне структурування тексту передбачає імітацію усного спілкування автора з читачем.

Ключові слова: літературна комунікачія, комунікативна стратегія, регулятивна стратегія, регулятивна тактика, регулятивний прийом.

Літературна комунікація є складним психічним процесом. У його основі - сприйняття не так фізичних подразників - друкованих літер, пунктуаційних знаків, площинного розташування компонентів тексту тощо, як закодованої в них інформації. Дешифрування художнього повідомлення, безперечно, зумовлене пресупозицією, рівнем асоціативного мислення й уяви, внутрішньою активністю реципієнта. Воно індивідуально-суб'єктивне, неповторне, варіативне, водночас передбачає інваріантний складник, генерований, з одного боку, фабулою твору, зображеним у ньому предметним світом і персонажами, з іншого - системою продуманих автором поетапних мовленнєвих дій, що є тактиками його регулятивної стратегії.

Регулятивна стратегія входить до загальної комунікативної стратегії тексту. За концепцією О. Іссерс (Issers), яка набула особливого поширення в лінгвістиці, комунікативні стратегії диференційовані на основні та допоміжні. Основні стратегії - семантичні, когнітивні - пов'язані із впливом на концептуальну свідомість адресата. Допоміжні стратегії зумовлені ситуацією, вони контролюють перебіг спілкування і привертання уваги читача до інформативно значущих фрагментів тексту. В усному спілкуванні таку роль здебільшого виконують риторичні, діалогові комунікативні стратегії, у художньому ж тексті цю функцію перебирають на себе регулятивні стратегії, що послідовно маркують основні етапи комунікативного процесу - кодування, вибір каналу зв'язку, передачу інформації, декодування. Отже, регулятивна стратегія постає окремим вектором мовленнєвої поведінки адресанта, маніфестує спеціальне художнє оброблення повідомлення з метою ефективного взаєморозуміння 3 адресатом в умовах асинхронного спілкування та відображає евристичну інтенційну програму планування дискурсної взаємодії автора з читачем, спрямованої на трансформацію моделі світу останнього.

Регулятивні стратегії візуалізовані за допомогою регулятивних тактик, що грунтуються на мовленнєвих уміннях, комунікативній компетенції, мотиві та інтенції автора. Тактику співвідносять із певним етапом утілення стратегії, на якому реалізують те чи те глобальне або локальне комунікативне завдання. Якщо стратегію асоціюють із метою, то тактику - із «практичним засобом руху до <... мети» (Klyuev 43). Окремі регулятивні тактики, їх перехрещення чи накладання стають платформою для реалізації основних комунікативних стратегій художнього тексту. Репрезентованість регулятивних тактик у художньому тексті-дискурсі може набувати таких форм, як монотактичність (регулятивна стратегія об'єктивована використанням однієї тактики) та політактичність (регулятивна стратегія передбачає кілька різних тактик). Цілеспрямований набір регулятивних стратегій та їхніх тактик завжди підконтрольний глобальному намірові й репрезентує регулятивне планування тексту. Регулятивне планування художнього тексту передбачає транслювання якнайточнішої інформації, сприймання якої залежатиме від характеру стимулювання пізнавального інтересу в реципієнта та його активності. Із цією метою регулятивне структурування тексту зорієнтоване на імітацію усного спілкування, створення ілюзії синхронної комунікації.

Регулятивна стратегія художнього тексту стала об’єктом студіювань лише нещодавно (див. праці, наприклад, Н. Болотнової, О. Асланової, Н. Камнєвої, Л. Карепіної, Н. Петрової, К. Шмугурової та ін.). Її специфікою беззаперечно визнано зорієнтованість на досягнення кооперативного результату. За ознакою дієвості (Кhауm 156174) регулятивну стратегію номіновано гнучкою, здатною вибудовувати різну лінію мовленнєвої поведінки продуцента: залежно від контекстних умов він або порушує принципи та норми стереотипної художньої комунікації, або прагне дотримуватися їх. Цей різновид комунікативної стратегії варто оцінювати й на тлі активно

(C) Галаур С., 2019 